\title{
Weldability Analysis of T23 Material for Superheater Coil
}

\author{
N.Jeyaprakash ${ }^{1}$, R. Prabhakaran ${ }^{2}$, G. Murugesan ${ }^{3}$ \\ ${ }^{1}$ (Asst.Professor,Department of Production Engineering,Defence University,Ethiopia,North Africa) \\ ${ }^{2}$ (Engineer - Welding, National Oil Well Varco, NOV India Pvt.Ltd,Chennai,India 600098) \\ ${ }^{3}$ (Engineer - Welding ,Toshiba JSW Power Systems Pvt.Ltd,Chennai,India 600103)
}

\begin{abstract}
In Fossil power boiler, super heater coil type panel is employed to convert saturated steam to super heated steam. Generally these panels are made by formation of thick wall low alloy steel like STEEL ALLOY213 TUBE-22 material. The power generating capacity of Fossil power boiler is $500 \mathrm{MW}$. This STEEL ALLOY213 TUBE-22 material has low creep strength and it cannot withstand continuous high temperature to rectify the above problem, the usage of an alternate material called STEEL ALLOY-213 TUBE-23 was attempted.The welding operation has been carried out in super heater coil by Tungsten Inert Gas (TIG) welding and Submerged Arc Welding (SAW). The welding analysis in STEEL ALLOY-213 TUBE-22 and STEEL ALLOY-213 TUBE-23 materials was carried out by four types of mechanical tests namely Impact Test, Tensile Test, Bend Test and Hardness Test.From the obtained results of the mechanical tests, it can be concluded that STEEL ALLOY-213 TUBE-23 material is having better creep strength while compared with STEEL ALLOY-213 TUBE22 material.
\end{abstract}

Keywords: Bend Test, Hardness Test, Impact Test, Sub merged arc welding, Tungsten Inert Gas Welding.

\section{Introduction}

The steam temperatures of most efficient fossil power plants are the $600^{\circ} \mathrm{c}$ which represents an increase of about $60^{\circ} \mathrm{c}$ in 30 years. With the recent advancement and technologies, it is expected to be further increased by around $50-100^{\circ} \mathrm{c}$. The need for higher thermal efficiency in fossil fired power plants has led to number of new material developments during past 10 year, which allowed the effective realization of steam temperature as high as $625^{\circ} \mathrm{c}$ during continuous operation.Ensuring higher steam parameters, however has also led to increasing requirements for the tube steels of super heater, which with can no longer be fulfilled with the previously used steels $\mathrm{T} 12$ or $\mathrm{T} 22$.

In addition to the higher creep rupture parameters, the construction of super heater also requires welding properties without the need for a post weld heat treatment (PWHT). These new requirements profiles lead to the development of the T23 steel. It proves not only suitable for being used as a super heater, but also offer favorable alternative $9 \% \mathrm{Cr}$ martensitic steel.

The advantages of these new steels are therefore not only important for power plants with high steam parameters, but also for new facilities with conventional parameters. This T23 steel contains alloying additions such as niobium, vanadium, boron, tungsten etc; this work concentrates on the effect of various alloying elements present in the T23 steels for the microstructural development and the mechanical properties improvement in the weld metal. Various steels have been made over the T23 material and the results are compared with the existing steels. Based on the results various properties such creep, hardness, toughness, yield strength has been discussed to determine the effective suitability of T23 superheater steel component.

\section{Chemical composition:}

\section{Experimental Procedure}

Chemical composition of steel grade T23 as per ASME Code ASTM A213/2199 are compared In the table 1.1 to other standard steel grades $(\mathrm{T} 22, \mathrm{~T} 92)$ used for similar high temperature application.

To develop grade T23 the basic T22 grade was modified by addition of tungsten (1.6\%) to reduction of molybdenum $(0.2 \%)$ and carbon contents $(0.04-0.10 \%)$ and small addition of vanadium, columbium(cb) nitrogen and boron. After proper heat treatment creep strength values and the resulting allowable stresses are greatly improved.

Table 1.1 Comparison of T22 with T23

\begin{tabular}{|c|c|c|c|c|c|c|c|c|c|c|c|}
\hline spec & $\mathrm{C} \%$ & $\mathrm{Si} \%$ & $\mathrm{Mn} \%$ & $\mathrm{Cr} \%$ & Mo\% & $\mathrm{W} \%$ & V\% & $\mathrm{Nb} \%$ & B\% & $\mathrm{Al} \%$ & N\% \\
\hline T22 & $<=.15$ & $0.25-1.0$ & $0.3-0.6$ & $1.9-2.6$ & $\begin{array}{l}0.87- \\
1.13\end{array}$ & -- & -- & -- & -- & -- & -- \\
\hline T23 & $0.04-0.10$ & $<=0.5$ & $\begin{array}{l}0.10- \\
0.60\end{array}$ & $1.9-2.6$ & $\begin{array}{l}0.05- \\
0.30\end{array}$ & $\begin{array}{l}1.4- \\
1.75\end{array}$ & $\begin{array}{l}0.20- \\
0.30\end{array}$ & $\begin{array}{l}0.02- \\
0.08\end{array}$ & $\begin{array}{l}0.0005- \\
0.0060\end{array}$ & $<=0.03$ & $<=0.030$ \\
\hline
\end{tabular}

carbon content was intentionally lowered with regards to weldability are strictly limited to ensure consistent behavior during manufacturing and fabrication as well as uniform creep resistance. 


\section{Tungesten Inert Gas Welding}

This process is manually operated some times it is fully automatic. Here tungsten is used as a filler rod and argon gases such as helium are used. The arc starting is achieved by additional equipment called high frequency arc starter. The power source should be capable of giving uniform penetration in arc length and melting of the filler wire. The TIG welding as in the fig 1. is used filling root gaps for the pipes/tubes.

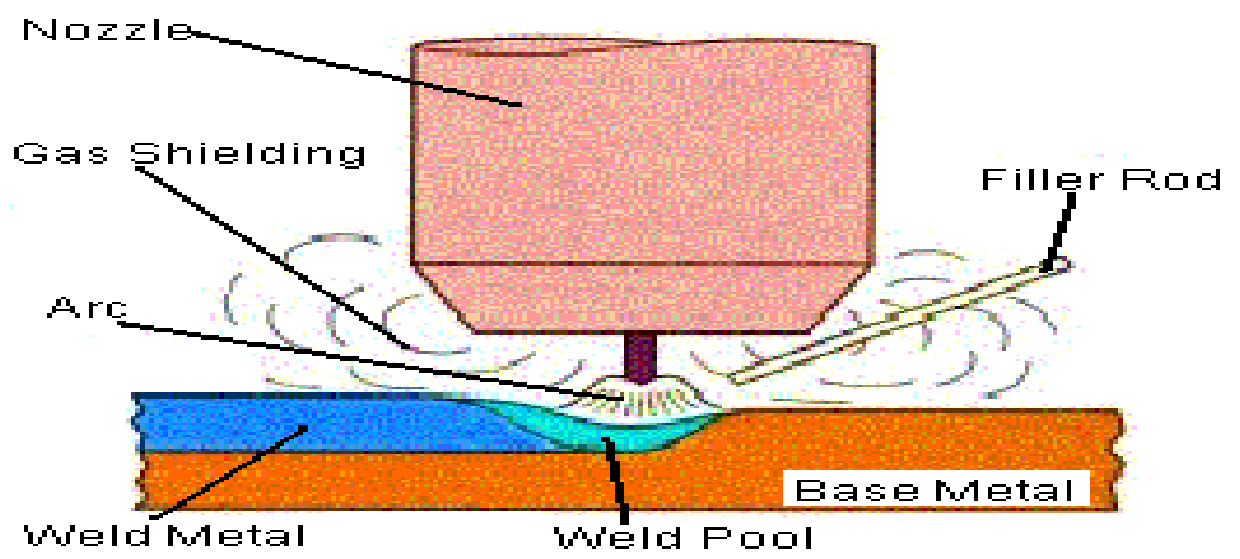

\section{Sub-Merged Arc Welding}

In the sub merged arc welding the end of the electrode arc is submerged in the flux and hence there is no visible sight of the arc. Welding current flow through the arc and the heat of the arc melts the electrodes, flux and some material to form a weld puddle that fills the joints. Sufficient depth of flux present in the process completely shields the arc column and protects the weld pool from atmospheric contamination. As a result of this unique protection, the weld beads are exceptionally smooth. The filler wire diameter varies from $2.0 \mathrm{~mm}$ to $6.3 \mathrm{~mm}$. The SAW is carried out to join the dished ends with the header pipe. The submerged arc welding is shown in the fig 2.

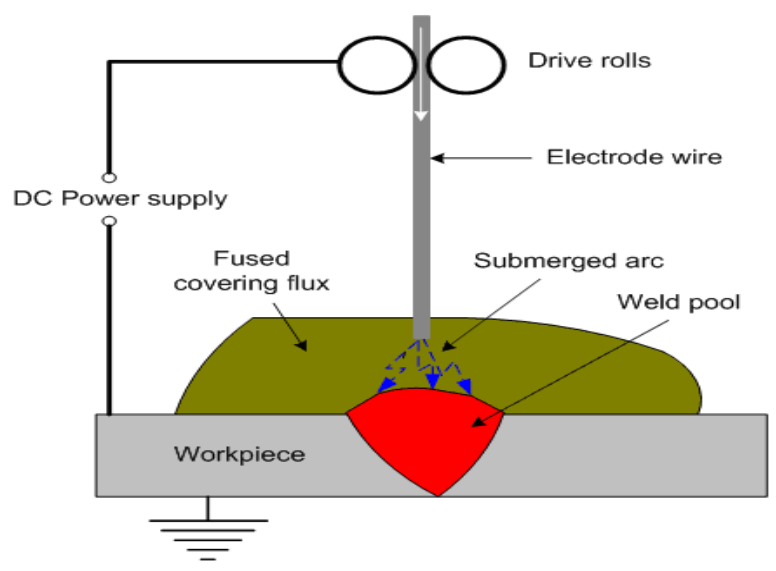

\section{Properties Of Welding Electrodes}

At first, a GTAW filler metal of the same composition was developed for the welding of these walled tubes for the construction of the super heater. In this case a PWHT can be waved, as the low carbon content prevents a hardness increase with values in excess of $350 \mathrm{Hv}$ both in the weld metal and the HAZ. It could be proved that this material is also well suited for the heavy wall components.

Table.1.2

\begin{tabular}{|c|c|c|c|c|c|c|c|c|c|c|}
\hline $\begin{array}{c}\text { WELDING } \\
\text { PROCESS }\end{array}$ & $\mathrm{C} \%$ & SI \% & MN \% & CR \% & NI \% & MO \% & V \% & W \% & NB \% & N \% \\
\hline GTAW & 0.08 & 0.27 & 0.54 & 2.14 & 0.04 & 0.08 & 0.21 & 1.58 & 0.031 & 0.001 \\
\hline SMAW & 0.06 & 0.22 & 0.46 & 2.28 & 0.12 & 0.02 & 0.28 & 1.72 & 0.043 & 0.017 \\
\hline
\end{tabular}




\section{Mechanical Properties Of Filler Metals}

Table 1.1 and 1.2 shows the chemical composition of matching filler metals and gives the mechanical properties for the various welding processes. In the pure GTA weld metal, the toughness with and without PWHT $\left(750^{\circ} \mathrm{C}\right)$ is above $200 \mathrm{~J}$ depending on the diameter and the welding parameters. Hardness values amount to approximate $270 \mathrm{HV}$ without PWHT and to about $250 \mathrm{HV}$ after the performance of the PWHT. SWAW process must be followed by a PWHT at $740{ }^{\circ} \mathrm{C}$ as otherwise the toughness will only reach about 20J. For welding higher thickness, it recommended to have root welding GTAW process.

Table 1.3

\begin{tabular}{|c|c|c|c|c|c|}
\hline $\begin{array}{c}\text { WELDING } \\
\text { PROCESS }\end{array}$ & $\begin{array}{c}\text { TEST TEMPERATURE } \\
\left({ }^{\circ} \mathrm{C}\right)\end{array}$ & PWHT $\left({ }^{\circ} \mathrm{C} / \mathrm{H}\right)$ & Y.S (MPA) & T.S (MPA) & ELONGATON $(\%)$ \\
\hline \multirow{3}{*}{ GTAW } & +20 & - & 639 & 818 & 21.4 \\
\cline { 2 - 6 } & +20 & $740 / 2$ & 520 & 620 & 20.2 \\
\cline { 2 - 6 } & +550 & $740 / 2$ & 426 & 449 & 625 \\
\hline \multirow{3}{*}{ SMAW } & +20 & $740 / 2$ & 509 & 553 & 19 \\
\cline { 2 - 6 } & +20 & $740 / 15$ & 421 & 350 & 25 \\
\cline { 2 - 6 } & +550 & $740 / 15$ & 32 & 26.7 & \\
\hline
\end{tabular}

Impact Test On T23 Material

Test conducted at : Mechanical Testing Lab Identification : T23

Type of test : Charpy V notch $2 \mathrm{~mm}$ depth

Specimen size $: 3 \times 10 \times 55 \mathrm{~mm}$

Test temperature $\quad: 0{ }^{\circ} \mathrm{c}$

Table 1.4 Impact Test on T23 Material

\begin{tabular}{|c|}
\hline Impact energy in joules \\
\hline 33 \\
\hline 19 \\
\hline 27 \\
\hline 22 \\
\hline 30 \\
\hline
\end{tabular}

TENSILE TEST ON T23 MATERIAL

Test conducted at : Mechanical testing lab

Identification : T23STI \& T23ST2

Room temperature $: 25^{\circ} \mathrm{C}$

Table 1.6 Tensile Test on T23 Material

\begin{tabular}{|c|c|c|c|}
\hline Identification & $\begin{array}{c}\text { Specimen size } \\
\text { in mm }\end{array}$ & $\begin{array}{c}\text { UTS in } \\
\text { Mpa }\end{array}$ & $\begin{array}{c}\text { Position of } \\
\text { fracture }\end{array}$ \\
\hline T23ST1 & $19.60 \times 4.20$ & 697 & Base Metal \\
\hline T23ST2 & $19.60 X 4.20$ & 697 & Base Metal \\
\hline
\end{tabular}

\section{BEND TEST ON T23 MATERIAL}

Test conducted at : Mechanical Testing Lab

Identification : T23FB1 \& T23RB1

Mandrel diameter $\quad: 4 \mathrm{t}$ (t-thickness of specimen)

Specimen size $: 3 \mathrm{~mm} \times 10 \mathrm{~mm} \times 55 \mathrm{~mm}$

Angel of bend $: 180^{\circ}$

Specimen size $: 5 \mathrm{~mm} \times 20 \mathrm{~mm} \times 180 \mathrm{~mm}$

Room temperature : $25{ }^{0} \mathrm{C}$

Table 1.8 Bend Test on T23 Material

\begin{tabular}{|c|c|c|c|}
\hline Identification & Root bend & Face bend & Remark \\
\hline T23FB1 & ----------- & $\begin{array}{c}\text { No open } \\
\text { discontinuity } \\
\text { observed }\end{array}$ & passed \\
\hline T23FB2 & $\begin{array}{c}\text { No open } \\
\text { discontinuity } \\
\text { observed }\end{array}$ & ------------- & passed \\
\hline
\end{tabular}

\section{HARDNESS TEST ON T23 MATERIAI}

Test conducted at : Mechanical Testing Lab

Identification : T1, T2

Room temperature : $25{ }^{\circ} \mathrm{C}$

$\begin{array}{ll}\text { Impact Test On T22 Material } \\ \text { Test conducted at } & : \text { Mechanical Testing Lab } \\ \text { Identification } & : \text { T22 } \\ \text { Type of test } & : \text { Charpy V notch } 2 \mathrm{~mm} \text { depth } \\ \text { Specimen size } & : 3 \times 10 \times 55 \mathrm{~mm} \\ \text { Test temperature } & : 0{ }^{\circ} \mathrm{C}\end{array}$

Table 1.5 Impact Test on T22 Material

\begin{tabular}{|c|}
\hline Impact energy in joules \\
\hline 11 \\
\hline 20 \\
\hline 10 \\
\hline 10 \\
\hline 21 \\
\hline
\end{tabular}

TENSILE TEST ON T22 MATERIAL

Test conducted at : Mechanical Testing Lab

Identification : T22T1, T22T2

Test temperature : $25^{\circ} \mathrm{c}$

Table 1.7 Tensile Test on T22 Material

\begin{tabular}{|l|l|l|l|}
\hline $\begin{array}{l}\text { Identificat } \\
\text { ion }\end{array}$ & $\begin{array}{l}\text { specimen } \\
\text { size }(\mathrm{mm})\end{array}$ & $\begin{array}{l}\text { UTS in } \\
\mathrm{MPa}\end{array}$ & Position of fracture \\
\hline T22T1 & $19.60 \times 3.60$ & 658 & Base metal \\
\hline T22T2 & $19.70 \times 3.80$ & 636 & Base metal \\
\hline
\end{tabular}

BEND TEST ON T22 MATERIAL

Test conducted at : Mechanical Testing Lab Identification : T22FB1, T22FB2

Mandrel diameter : $4 \mathrm{t}$ (t-thickness of specimen)

Specimen size $\quad: 3 \mathrm{~mm} \times 10 \mathrm{~mm} \times 55 \mathrm{~mm}$

Angel of bend $\quad: 180^{\circ}$

Specimen size $\quad: 5 \mathrm{~mm} \times 20 \mathrm{~mm} \times 180 \mathrm{~mm}$

Room temperature $: 25{ }^{\circ} \mathrm{C}$

Table 1.9 Bend Test on T22 Material

\begin{tabular}{|l|c|c|c|}
\hline Identification & Root bend & Face bend & Remark \\
\hline T22FB1 & ----------- & $\begin{array}{c}\text { No open } \\
\text { discontinuity } \\
\text { observed }\end{array}$ & passed \\
\hline T22FB2 & $\begin{array}{c}\text { No open } \\
\text { discontinuit } \\
\text { y observed }\end{array}$ & ------------- & passed \\
\hline
\end{tabular}

HARDNESS TEST ON T22 MATERIAL

Test conducted at : Mechanical Testing Lab

Identification : T1, T2

Room temperature : $25^{0} \mathrm{C}$ 
Weldability Analysis of T23 Material for Superheater Coil

Table 1.10 Hardness Test on T23 Material

\begin{tabular}{|c|c|c|}
\hline S.No & $\begin{array}{c}\text { Hardness } \\
\text { Value For } \\
\text { IDFN.T1 }\end{array}$ & Hardness Value For IDFN.T2 \\
\hline 1 & 230 & 211 \\
\hline 2 & 224 & 218 \\
\hline 3 & 227 & 205 \\
\hline
\end{tabular}

Table 1.11 Hardness Test on T22 Material

\begin{tabular}{|c|c|c|}
\hline S.No & $\begin{array}{c}\text { HARDNESS } \\
\text { VALUE FOR } \\
\text { IDFN.T1 }\end{array}$ & $\begin{array}{c}\text { HARDNESS VALUE FOR } \\
\text { IDFN.T2 }\end{array}$ \\
\hline 1 & 227 & 233 \\
\hline 2 & 219 & 233 \\
\hline 3 & 225 & 224 \\
\hline
\end{tabular}

III. Conclusion

In this project studies has been carried out about the super heater coil used in fossil power boiler. The super heater made up of Steel Alloy 213 Tube 22 material. During the continuous operation this material cannot withstand high temperature. So efforts have been put in this project to replace Steel Alloy 213 Tube 22 material to newer material. It has been found that Steel Alloy 213 Tube 23 material have some special mechanical properties than Steel Alloy 213 Tube 22 material.

The mechanical tests like impact, tensile, bend and hardness has been carried out in Steel Alloy 213 Tube 22 and Steel Alloy 213 Tube 23 materials. The results confirm that Steel Alloy 213 Tube 23 material can withstand high load even in the high temperature than Steel Alloy 213 Tube 22 material.

\section{Reference}

[1]. K. Laha, K.S. Chandravathi, K. BhanuSankaraRao, and S.L.Mannan: Metall. Mater. Trans. A, 2001, vol. 32A, pp. 115-24.

[2]. M Barrie (1997) "Fabrication of steels for advanced power plant", Mitsui Babcock Energy Ltd.,

[3]. A.K. Bhaduri, S. Venkadesan, and P. Rodriguez: Int. J. Pres. Ves.Pip., 1994, vol. 58, pp. 251-65.

[4]. M.F.Brady (1965) "Design aspects of once through systems for heat recovery steam generators for base load and cyclic operatio", Innovate Steam Technologies Ltd.,

[5]. J.D. Parker: Mater. High Temp., 1994, vol. 11, pp. 25-33.

[6]. J.D. Parker and G.C. Stratford: J. Mater. Sci., 2000, vol. 35,pp. 4099-4107.

[7]. Y. Gong, J. Cao, L. Ji, C. Yang, C. Yao, Z. Yang, J. WangX. Luo, F. Gu, A. Qi, S. Ye, and Z. Hu: Fatigue Fract. Eng.Mater. Struct.,2011, vol. 34 (2), pp. 83-96.

[8]. M. Yamazaki, T. Watanabe, H. Hongo, and M. Tabuchi: J. Power Energy Systems, 2008, vol. 2 (4), pp. 1140-49.

[9]. J. An, H. Jing, G. Xiao, L. Zhao, and L. Xu: J. Mater. Eng. Perform., Nov. 6, 2010, online.

[10]. Gerhard Buschamann, Herbert Clemens, "The Steam Engine-Status of Development and Market Potential".

[11]. F. Gauzziand S. Missori: J. Mater. Sci., 1988, vol. 23, pp. 782-89. 